\title{
PENGEMBANGAN SISTEM PENUNJANG KEPUTUSAN DALAM MENENTUKAN PROGRAM INSEMINASI BUATAN HEWAN TERNAK MENGGUNAKAN METODE WHAT-IF ANALYSIS
}

\author{
Indah Fitria ${ }^{1}$, Nurudin Santoso $^{2}$, Arief Prasetyo $^{3}$ \\ Program Studi Teknik Informatika, Jurusan Teknologi Informasi, Politeknik Negeri Malang \\ JL. Soekarno-Hatta No. 9 Malang 65141, Indonesia \\ 1itria.indah12@gmail.com, ${ }^{2}$ nurudin@ @olinema.ac.id, ${ }^{3}$ arief.prasetyo@ polinema.ac.id
}

\begin{abstract}
Abstrak
Salah satu misi dari Dinas Peternakan dan Kesehatan Hewan Kabupaten Malang yaitu meningkatkan populasi dan produktifitas ternak. Ada target peningkatan populasi dan produktifitas ternak yang harus dicapai setiap tahunnya. Salah satu program kerja untuk mencapai misi tersebut adalah dengan memberikan inseminasi buatan. Dalam program pemberian inseminasi buatan, Dinas harus menentukan dosis semen beku dan target kelahiran.

Saat ini penentuan dosis semen beku dan target kelahiran masih menggunakan cara manual berdasarkan data tahun-tahun sebelumnya. Penelitian ini mengembangkan sistem informasi yang dapat membantu merekomendasikan target kelahiran dan populasi menggunakan metode What-if Anaysis.

What-If Analysis dapat disebut sebagai suatu simulasi data yang tujuannya adalah untuk menganalisis karakteristik atau sifat dari sistem yang kompleks di bawah suatu hipotesis yang diberikan. Selain itu, What-If Analysis dapat digunakan untuk mengetahui perubahan yang terjadi terhadap dependentvariables (variabel yang menyebabkan atau memengaruhi) jika ada perubahan pada independentvariables (pengaruh dependent variables).

Dari pengujian terhadap sistem informasi yang dikembangkan, menggunakan data tahun 2012 sampai tahun 2015, diperoleh hasil tingkat akurasi sebesar 89,3\% untuk taget populasi dan $84,84 \%$ untuk target kelahiran inseminasi buatan. Hal ini menunjukkan bahwa penggunaan metode what-if analysis cukup tepat utk digunakan dalam program kerja inseminasi buatan pada Dinas Peternakan dan Kesehatan Hewan
\end{abstract}

Kata kunci : Sistem Peramalan, What-if Analysis, Inseminasi Buatan, Populasi

\section{Pendahuluan}

Berdasarkan statistika Dinas Peternakan Jawa Timur, jumlah produksi hewan ternak di Kabupaten Malang mengalami naik turun selama 5 tahun terakhir. Hewan ternak yang masuk kedalam pengawasan ada 12 komoditas yaitu terbagi kedalam 3 jenis ternak. Diantaranya ternak besar, ternak kecil dan unggas. Ketiga jenis ternak meliputi sapi potong, sapi perah, kambing, domba, babi, kerbau, kuda, ayam buras, ayam petelur, ayam pedaging, itik dan entok.

Dinas Peternakan dan Kesehatan Hewan Kabupaten Malang dalam salah satu misinya yaitu meningkatkan populasi dan produktifitas ternak. Berkaitan dengan ini setiap tahunnya Dinas Peternakan dan Kesehatan Hewan Kabupaten Malang mempunyai target populasi yang akan dicapai. Salah satu langkah untuk mencapai misi tersebut adalah dengan menyusun program kerja yang strategis dan efisien. Berdasarkan program kerja yang telah dijalankan, salah satunya adalah inseminasi buatan (IB).

Inseminasi buatan (IB) merupakan salah satu teknologi tepat guna yang dapat digunakan untuk memanfaatkan penggunaan bibit jantan unggul dalam perbaikan mutu ternak pada sapi (perah, potong), kambing (Ditjen Peternakan, 1993).

Dalam program IB dilakukan peramalan untuk menentukan target yang akan dicapai dalam periode satu tahun. Dalam penelitian ini peramalan menggunakan metode what-if analysis, dengan metode ini dapat menjadi solusi karena dengan mensimulasikan data yang tujuannya adalah untuk menganalisis karakteristik atau sifat dari sistem yang kompleks di bawah suatu hipotesis yang diberikan. Jadi perhitungan peramalan akan dilakukan dengan fleksibel sesuai dengan kebutuhan pengguna. Sehingga mendapatkan hasil yang optimal. 


\section{Metode What-if Analysis}

What-If Analysis adalah sebuah analisis kuantitatif dengan pendekatan kualitatif, menggunakan pertanyaan yang bersifat umum dan luas untuk mengetahui kemungkinan yang akan terjadi dari suatu masalah yang ada.

Untuk dapat mengenal lebih jauh mengenai What-If Analysis, berikut

karakteristiknya:

a. What-If Analysis adalah sebuah perkiraan yang sistematik, yang dilakukan oleh tim yang terdiri dari orang yang ahli dibidangnya untuk membuat analisis rangkuman dari masalah yang ada secara menyeluruh dan untuk memastikan bahwa penanganan terhadap masalah dilakukan secara benar.

b. What-If Analysis biasanya dilakukan oleh satu atau lebih tim dengan latar belakang dan pengalaman yang berbeda, yang terlibat dalam sebuah grup untuk melakukan eksplorasi terhadap masalah yang ada.

c. What-If Analysis digunakan sebagai teknik untuk memperkirakan dan menganalisis resiko secara detil.

d. What-If Analysis membuat deskripsi kualitatif dari masalah yang ada, dalam bentuk pertanyaan dan jawabannya, juga kumpulan rekomendasi atau saran untuk mencegah timbulnya masalah tersebut.

e. Kualitas dari proses evaluasi tersebut tergantung dari kulitas dokumentasi yang diperoleh, pelatihan yang dilakukan oleh pimpinan tim, dan pengalaman dari tim yang melakukan pengembangan.

f. Secara umum What-If Analysis dapat diaplikasikan untuk hampir semua aplikasi analisa resiko, terutama resiko dengan skenario kegagalan yang kecil dan sederhana.

g. What-If Analysis dapat berdiri sendiri, tetapi umumnya digunakan sebagai pelengkap metode pengambilan keputusan lainnya atau metode yang lebih terstruktur.

Langkah-langah metode what-if analysis, antara lain:

1) Mendefiniskan aktifitas atau sistem apa yang akan dianalisis

2) Mendefinisikan masalah yang ada saat ini.

3) Membagi-bagi masalah menjadi bagian yang lebih kecil untuk dianalisis.

4) Membuat pertanyaan yang berbentuk "What-If" untuk setiap elemen aktifitas atau sistem yang ada.

5) Menjawab pertanyaan yang sudah dibuat

6) Elemen atau aktifitas yang terdapat dalam sistem dapat dibagi-bagi lagi menjadi lebih kecil

7) Menggunakan hasil tersebut untuk membuat keputusan terhadap

\section{Perancangan dan Implementasi}

Berikut adalah perancangan dan implementasi sistem yang digunakan unntuk mencapai terbangunnya sistem informasi yang dapat membantu menyelesaikan masalah dan menerapkan metode what-if analysis.

\subsection{Perancangan Sistem}

Perancangan sistem terdiri dari use case, flowchartperhitungan metode What-if Analysis, data populasi dan data inseminasi buatan.

\subsubsection{Flowchart Perhitungan What-if Analysis}

Berikut diagram perhitungan metode what-if analysis ditunjukkan dalam bentuk flowchart:

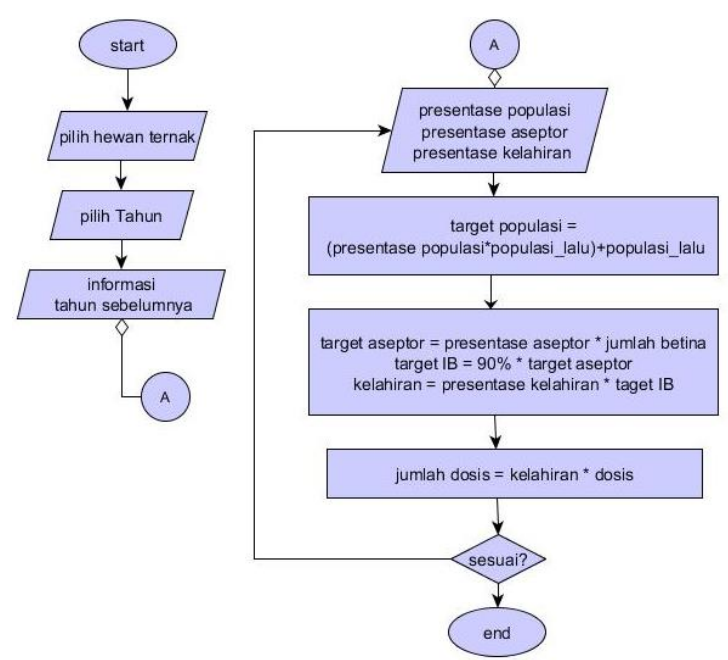

Gambar 1 Flowchart Perhitungan What-if Analysis

\subsubsection{Use Case}

Sistem yang akan dibangun adalah Sistem Penunjang Keputusan Dalam Menentukan Program Inseminasi Buatan. User pada sistem ini ada 3, yaitu:

Tabel 1 Definisi Aktor Pada Diagram Use Case

\begin{tabular}{|l|l|l|}
\hline No & Aktor & Kebutuhan Fungsional \\
\hline 1 & $\begin{array}{l}\text { Kepala } \\
\text { Bagian }\end{array}$ & $\begin{array}{l}\text { Orang yang menjadi } \\
\text { superuser dan berhak } \\
\text { mengelola semua fitur }\end{array}$ \\
\hline 2 & $\begin{array}{l}\text { Orang yang melakukan } \\
\text { keramalan pada program } \\
\text { Seksi }\end{array}$ & $\begin{array}{l}\text { inseminasi buatan. Selain itu } \\
\text { juga dapat melihat data } \\
\text { aktual dan perkembangan } \\
\text { program inseminasi buatan }\end{array}$ \\
\hline 3 & Admin & $\begin{array}{l}\text { Orang yang bertugas } \\
\text { memanajemen data aktual, } \\
\text { yaitu input, ubah, dan hapus } \\
\text { data aktual Kabupaten dan di } \\
\text { setiap kecamatan. }\end{array}$ \\
\hline
\end{tabular}


Berikut merupakan penjelasan fitur-fitur yang ada pada sistem ditampilkan dalam bentuk use case diagram:

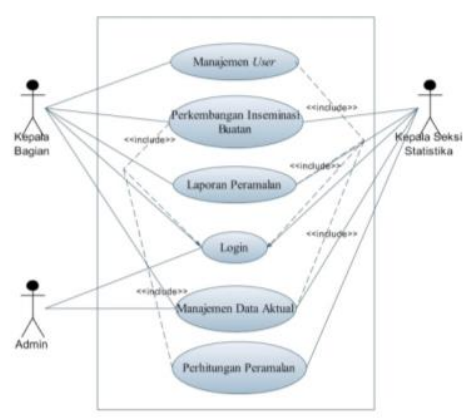

Gambar 2 Use Case

\subsubsection{Data}

Untuk menghasilkan peramalan, sistem ini membutuhkan data yang dapat mendukung pengambilan keputusan. Data yang digunakan dalam sistem ini, antara lain:

a. Data Populasi

Data populasi adalah data jumlah hewan ternak yang akan digunakan sebagai data acuan peramalan. Data populasi terdiri dari data populasi jantan dan betina hewan ternak Kabupaten Malang dan data di setiap kecamatan.

b. Data Inseminasi Buatan

Data inseminasi buatan adalah data yang menjelaskan secara rinci aspek aspek yang digunakan dalam program. Data inseminasi buatan terdiri dari data kelahiran ternak di Kabupaten Malang dan setiap kecamatan dan data dosis semen beku yang dipakai di kabupaten Malang dan disetiap kecamatan.

\subsection{Implementasi}

Setelah melakukan tahapan perancangan aplikasi, maka pada bab ini akan dibahas tentang proses implementasi, yaitu realisasi perancangan menjadi nyata. Bagian pada bab ini meliputi implementasi basis data dan implementasi sistem.

\subsubsection{Implementasi Basis Data}

Implementasi basis data dilakukan sesuai dengan perancangan yang telah dilakukan. Basis datayang dibuat diberi nama db_spkkinerja. Pada basis data disnak memiliki 7 tabel yaitu tabel aktual, tabel det aktual, tabel det ramal, tabel kecamatan, tabel ramal, tabel ternak, dan tabel user

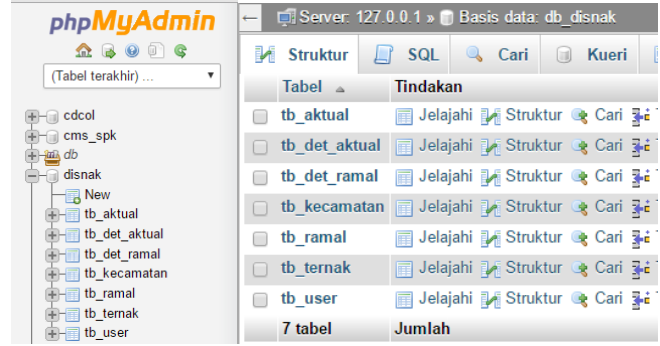

Gambar 3 Basis Data Disnak

\subsubsection{Implementasi Program}

Implementasi Sistem Informasi ini dilakukan dengan bahasa pemrograman PHP.

1) Halaman Peramalan

Merupakan halaman untuk menentukan target populasi dan target kelahiran berdasarkan target aseptor yang dipilih user.

2) Halaman Hasil Peramalan

Menggambarkan halaman hasil perhitungan target populasi dan target kelahiran. Selanjutnya user dapat memilih dosis semen beku.
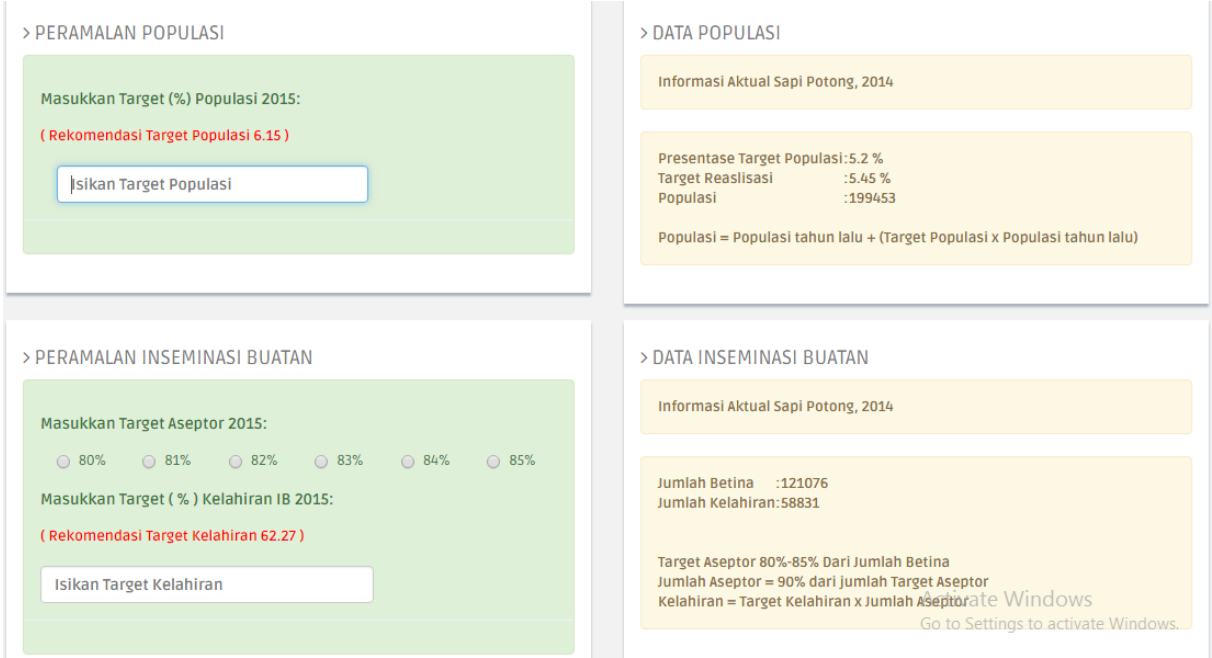

Gambar 4 Halaman Input Peramalan 


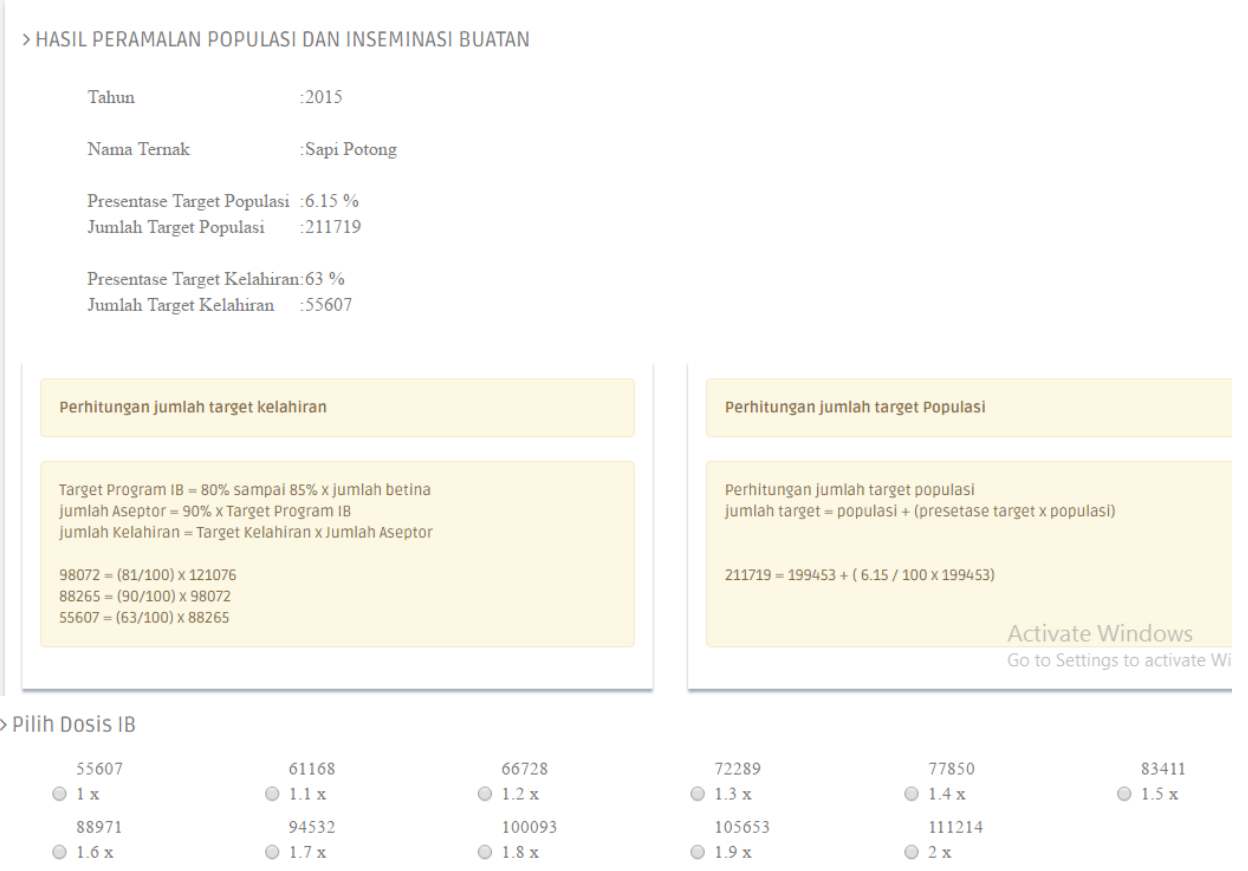

Gambar 5Halaman Hasil Peramalan

\section{Pengujian dan Pembahasan}

\subsection{Black Box Testing}

Black box testing adalah teknik pengujian yang berfokus pada keluaran hasil dari respon masukan, atau secara sederhana black box merupakan proses menjalankan aplikasi untuk mengetahui apakah ada error atau ada fungsi yang tidak berjalan sesuai harapan. Black box testing mengabaikan mekanisme internal sistem, seperti bagaimana sistem bekerja memproses masukan

\subsection{Pengujian Sistem}

Pengujian ini dilakukan dengan caramenghitung ketepatan perhitungan metode dengan bantuan pendukung aplikasi Microsoft Excel. Hasil dari pengujian manual menggunakan Microsoft Excel akan dicocokan dengan hasil pengujian sistem. Pengujian sistem diantaranya yaitu pengujian perhitungan metodeWhat-if Analysis. Pada pengujian perhitungan digunakan data tahun 2012 sampai 2015 untuk menentukan target populasi dan target inseminasi buatan.

\subsection{Pengujian Akurasi}

Pengujian akurasi sistem terhadap data aktual dilalakukan dengan cara membandingkan hasil peramalan sistem dengan data akual dari Dinas. Menggunakan treshold 20\%.

Tabel 2 Data Uji Populasi

\begin{tabular}{|r|r|r|r|r|l|}
\cline { 3 - 5 } \multicolumn{2}{c|}{} & \multicolumn{2}{c|}{ Persentase } & \multicolumn{2}{c|}{} \\
\hline Tahun & Populasi & Target & Kenaikan & selisih & Ket \\
\hline 2012 & 240.746 & 6,4 & 6,17 & 0,23 & Acuan \\
\hline 2013 & 189.145 & 4,4 & $-21,43$ & 25,83 & Treshold \\
\hline 2014 & 199.453 & 5,2 & 5,45 & $-0,25$ & \\
\hline & & & & & \\
2015 & 212.821 & 4,8 & 6,70 & $-1,90$ & \\
\hline
\end{tabular}

Tabel 3 Data Uji Kelahiran

\begin{tabular}{|r|c|c|c|c|c|r|r|r|r|}
\cline { 7 - 9 } Tahun & Populasi & Jantan & Betina & Kelahiran & Dosis & $80 \%$ & $90 \%$ & $\begin{array}{l}\text { Presentase } \\
\text { kelahiran }\end{array}$ & Ket \\
\hline 2012 & 240.746 & 99.493 & 141.253 & 50.282 & 78.398 & 113.002 & 101.702 & 49,4 & Acuan \\
\hline 2013 & 189.145 & 73.007 & 116.138 & 58.438 & 73.688 & 92.910 & 83.619 & 69,9 & \\
\hline 2014 & 199.453 & 78.377 & 121.076 & 58.831 & 79.931 & 96.861 & 87.175 & 67,5 & \\
\hline 2015 & 212.821 & 85.819 & 127.002 & 59.714 & 84.001 & 101.602 & 91.441 & 65,3 & \\
\hline
\end{tabular}

\subsection{Pembahasan}

Dari percobaan pengujian sistem dan perbandingan dengan data aktual didapatkan bahwa penentuan target populasi data 2012 digunakan sebagai acuan uji coba. Sedangkan data 2013 peramalan populasi tidak bisa digunakan sebagai salah satu parameter peramalan karena kenaikan 
populasi melebihi treshold yang telah ditentukan jadi data 2013 tidak dapat dijadikan acuan untuk peramalan. Maka dari itu diperoleh data keluaran rekomendasi sistem untuk target populasi ditahun 2014-2015 dan dibandingkan dengan realisasi target aktual. Untuk tingkat keakurasian perbandingan antara perhitungan secara manual dan pada sistem, hasil pengujian menunjukkan bahwa presentse kecocokan sistem dengan data aktual untuk peramalan 2012-2015 adalah rata-rata 89,3 $\%$. Dengan rincian tingkat kecocokan 2014 sebesar $86,86 \%$ dan tahun 2015 sebesar $91,79 \%$.

Sedangkan untuk target kelahiran inseminasi buatan hasil akurasi sistem pada peramalan target 2013-2015 dengan acuan target 2012 menunjukkan jika user menginputkan target aseptor $80 \%$ maka hasil dari target kelahiran dan akurasi peramalan yang telah dibandingkan dengan data aktual sebagai berikut:

Tabel 4 Akurasi Peramalan Kelahiran

\begin{tabular}{|c|c|c|c|}
\hline Tahun & kelahiran (\%) & Rekomendasi & Akurasi( \%) \\
\hline 2012 & 49,4 & Acuan & Acuan \\
\hline 2013 & 69,9 & 49,4 & 70,74 \\
\hline 2014 & 67,5 & 59,7 & 88,41 \\
\hline 2015 & 65,3 & 62,3 & 95,36 \\
\hline
\end{tabular}

sistem ini telah berhasil dilakukan setelah melakukan implementasi pada sistem penilaian kinerja karyawan dengan menerapkan metode AHP dan TOPSIS menghasilkan hasil yang sama dengan hasil perhitungan pengujian manual. Hal ini dibuktikan dengan mengambil jumlah 5 data sampel karyawan dan 8 data kriteria penilaian, telah menghasilkan hasil keputusan sesuai dengan yang diharapkan. Berikut hasil analisa pengujian sistem.

Hasil pengujian menunjukkan bahwa presentse kecocokan sistem dengan data aktual untuk peramalan kelahiran tahun 2012-2015 adalah rata-rata $84,84 \%$. Pada peramalan program inseminasi buatan tingkat akurasi dapat berbeda disetip tahunnya. Dan target progam inseminasi buatan yang akan dicapai disesuaikan dengan semen beku yang akan disiapkan.

\section{Kesimpulan dan Saran}

\subsection{Kesimpulan}

Dari hasil uji coba yang dilaksanakan pada sistem penunjang keputusan dalam menentukan program inseminasi buatan hewan ternak menggunakan metode what-if analysis, dapat diambil kesimpulan sebagai berikut :

a. Sistem ini telah berhasil menerapkan metode what-if analysis, untuk sistem penunjang keputusan dalam menentukan program inseminasi buatan hewan ternak pada Dinas Peternakan dan kesehatan Hewan.

b. Hasil pengujian menunjukkan bahwa perancangan sistem telah menghasilkan sistem yang dapat membantu menunjang keptusan dalam menentukan inseminasi buatan hewan ternak dengan output data peramalan yang ditambah dengan rekomendasi sistem. Rekomendasi sistem didapatkan dari perhitungan rata-rata kenaikan aktual ditambah dengan hasil statndar deviasi dari selisih antara target dan kenaikan aktual. Data yang dihasilkan memiliki selisih yang lebih sedikit antara target dan data aktual dibandingkan dengan perhitungan manual dan user akan lebih efektif dan efisien mengguakan sistem peramalan ini.

c. Hasil pengujian menunjukkan bahwa sistem ini sudah menghasilkan hasil yang cukup akurat. Hasil menunjukkan bahwa peramalan dengan data 2012-2015 menghasilkan tingkat keakurasian $89,3 \%$ dalam menentukan target populasi dan $84,84 \%$ dalam menentukan kelahiran pada inseminasi buatan.

\subsection{Saran}

Sistem Penelitian ini masih dapat dikembangkan menjadi sistem yang lebih komplek, tidak hanya terfokus pada populasi dan inseminasi buatan saja. Berikut merupakan hal yang disarankan untuk pengembangan sistem informasi ini :

a. Untuk penelitian selanjutnya, perlu ditambahkannya fungsi evaluasi program inseminasi buatan sehingga Dinas Perternakan dan Kesehatan Hewan dapat melihat secara detail keberhasilan program yang telah dilakukan.

b. Dalam proses input data populasi dan inseminasi buatan, disarankan untuk menambahkan fungsi upload file dalam jumlah lebih besar yang berformat .csv, .txt, dll. Sehingga proses input tidak hanya dilakukan dengan cara satu per satu. Diharapkan hal tersebut dapat menghemat waktu dalam perekapan data populasi dan inseminasi buatan.

\section{Daftar Pustaka:}

Alexander Sibero. 2012. Kitab Suci Web Programing. Mediakom. Yogyakarta

Arief, M.Rudianto. 2011. Pemrograman Web Dinamis Menggunakan Php dan Mysql. Yogyakarta: ANDI

Belanová Katarína. 2012. “What If” Analyses In Investment Decision Making. University of Economics in Bratislava. Slovakia 
Gaspersz, Vincent. 1998. Production Planning and Inventory Control. Jakarta: Gramedia Pustaka Utama.

Informasi Dinas Peternakan Provinsi Jawa Timur.

[Online] Tersedia :

http://disnak.jatimprov.go.id/ [ 6 Desember 2015]

Kumalasari Vidyanita.2008. Penerapan What-If Analysis pada Sistem Penunjang Keputusan dalam Menentukan Menu Diet. Fakultas Ilmu Komputer Universitas Indonesia

M. Golfarelli, S. Rizzi .2008. UML-Based

Modeling for What-If Analysis. Proceedings

10th International Conference on Data

Warehousing and Knowledge Discovery.Turin, Italy.

Surat keputusan Direktur Jenderal Peternakan No. 112/TN.270/Kpts/DJP/Deptan/ 02/97 tentang syarat dan spesifikasi teknis semen beku sapi dan kerbau serta alat penyimpanannya. 